九州大学学術情報リポジトリ

Kyushu University Institutional Repository

\title{
Purification and Characterization of an Endo- $\beta$-Mannanase from Aeromonas sp. F-25
}

Araki, Toshiyoshi

Department of Fisheries, Faculty of Agriculture, Kyushu University

https://doi.org/10.5109/23762

出版情報: 九州大学大学院農学研究院紀要. 27 (3/4)，pp. 89-98，1983-02. Kyushu University バージョン：

権利関係 : 
J. Fac. Agr., Kyushu Univ., 27 (3 • 4), 89-98 (1983)

\title{
Purification and Characterization of an Endo- $\beta$-Mannanase from Aeromonas sp. F-25
}

\author{
Toshiyoshi Araki \\ Department of Fisheries, Faculty of Agriculture, \\ Kyushu University 46-04, Fukuoka 812 \\ (Received July 2, 1982)
}

\begin{abstract}
An endo- $\beta$-mannanase $(1,4-\beta$-D-mannan mannanohydrolase, EC 3. 2. 1. 78.) was isolated from the culture fluid of strain no. F-25 of Aeromonas hydrophila subspecies anaerogenes, and purified about 440 -fold by ammonium sulfate precipitation, and column chromatographies on DEAE-Sephadex A-50, Amberlite CG-50, Sephadex G-100, and hydroxylapatite. The final enzyme preparation was regarded as being homogeneous on polyacrylamide gel electrophoresis. The enzyme had a molecular weight of $24,000, \mathrm{pI}$ of $5.6, \mathrm{pH}$ optimum of 5.5, and was stable in a $\mathrm{pH}$ region of 5.0 to 9.0 and at temperatures below $45^{\circ} \mathrm{C}$. The enzyme hydrolyzed at random the internal $\beta$-1, 4-linkages in mannotetraose and larger oligosaccharides, and in codium mannan, coffee mannan, konjac glucomannan and guar gum galactomannan to give various sizes of oligosaccharides. It did not act on mannobiose and mannotriose.
\end{abstract}

\section{INTRODUCTION}

$\beta$-Mannan, as well as cellulose and xylan, is an important structural component of plant cell walls. It is distributed in several seaweeds (Jones, 1950; Love and Percival, 1964), besides in terrestrial plant seeds such as ivory nut (Aspinall et al., 1953) and coffee beans (Wolfrom et al.. 1961). For the structural analysis of this polysaccharide, $\beta$-mannanase should be a useful tool.

Recently we isolated a bacterium which secretes exo- and endo- $\beta$-mannanases into the culture fluid from natural habitat (Araki and Kitamikado, $1978,1981)$. The exo- $\beta$-mannanase from the bacterium was a novel glycosidase that removes mannobiose residue successively from the non-reducing end of the $\beta$-mannan molecule (Araki and Kitamikado, 1982). This paper describes the purification and characterization of the endo- $\beta$-mannanase being another enzyme.

\section{MATERIALS AND METHODS}

\section{Microorganism}

The organism used was strain no. F-25 of Aeromonas hydrophila subspecies anaerogenes isolated from intestinal contents of rainbow trout Salmo gairdnerii in 
1973,

\section{Materials}

Codium mannan (Love and Percival, 1964), coffee mannan (Wolfrom et al., 1961), konjac glucomannan (Sugiyama et al., 1972), and guar gum galactomannan (Heyne and Whistler, 1948) were prepared from Codium fragile, coffee beans, Amorphophallus konjac, and guar gum, respectively by the procedures reported previously. Konjac powder was obtained commercially.

Mannooligosaccharides were prepared by the method described in the previous paper (Araki and Kitamikado, 1982).

\section{Enzyme assay}

The reaction mixture consisted of $10 \mathrm{mg}$ of codium mannan, $2.0 \mathrm{ml}$ of 50 $\mathrm{mM}$ sodium acetate buffer, $\mathrm{pH} 5.5$, and $0.5 \mathrm{ml}$ of the enzyme solution. After incubation at $37^{\circ} \mathrm{C}$ for $10 \mathrm{~min}$, the reaction was stopped by heating the mixture in a boiling water bath for 5min. Reducing sugar produced was then determined by the Somogyi-Nelson's method (Somogyi, 1952) and expressed as mannose. One unit of $\beta$-mannanase is defined as the activity that produces reducing capacity equivalent to $1 \mu \mathrm{mol}$ of mannose per min under the above condition.

\section{Purification of endo- $\beta$-mannanase}

\section{Step I. Preparation of culture fluid}

The organism was cultured at $25^{\circ} \mathrm{C}$ for 3 days in Iiquid medium containing $1.0 \%$ peptone, $0.1 \%$ yeast extract, $0.05 \% \mathrm{MgSO}_{4} .7 \mathrm{H}_{2} \mathrm{O}, 0.2 \% \mathrm{~K}_{2} \mathrm{HPO}_{4}, 0.05 \%$ $\mathrm{KH}_{2} \mathrm{PO}_{4}, 0.5 \% \mathrm{NaCl}$, and $0.5 \%$ konjac powder, $\mathrm{pH} 7.0$. The culture was cenfrifuged at $15,000 \mathrm{~g}$ for $30 \mathrm{~min}$. From $8,000 \mathrm{ml}$ of liquid culture, 7,700 $\mathrm{ml}$ of clear culture fluid was obtained. All the remaining steps were conducted between 0 and $5^{\circ} \mathrm{C}$, and centrifugations were carried out at $17,000 \mathrm{~g}$ for $30 \mathrm{~min}$.

Step 2. Ammonium sulfate precipitation

The culture fluid was adjusted to $75 \%$ saturation with solid ammonium sulfate, and allowed to stand overnight. The precipitate was collected by centrifugation, and dissolved in $200 \mathrm{ml}$ of distilled water.

\section{Step 3. Chromatography on DEAE-Sephadex A-50}

The enzyme solution from the previous step was dialyzed against $10 \mathrm{mM}$ sodium acetate buffer, $\mathrm{pH} 6.0$, containing $2 \mathrm{mM}$ calcium acetate for 2 days. The dialyzed enzyme solution was applied to a column $(2.2 \times 42 \mathrm{~cm})$ of DEAESephadex A-50 equilibrated with the same buffer. After washing with 6 bed volumes of the same buffer, the column was eluted with $40 \mathrm{mM}$ sodium acetate buffer, pH 6.0, containing $2 \mathrm{mM}$ calcium acetate. The minor enzyme activity appeared in tube numbers 52 to 85 was due to the presence of exo- $\beta$-mannanase. The procedures of purification and characterization of the exo-enzyme was described in the previous paper (Araki and Kitamikado, 1982). The column was finally eluted with a continuous linear gradient between $500 \mathrm{ml}$ of $40 \mathrm{mM}$ sodium acetate buffer, $\mathrm{pH} 6.0$, containing $2 \mathrm{mM}$ calcium acetate and 500 


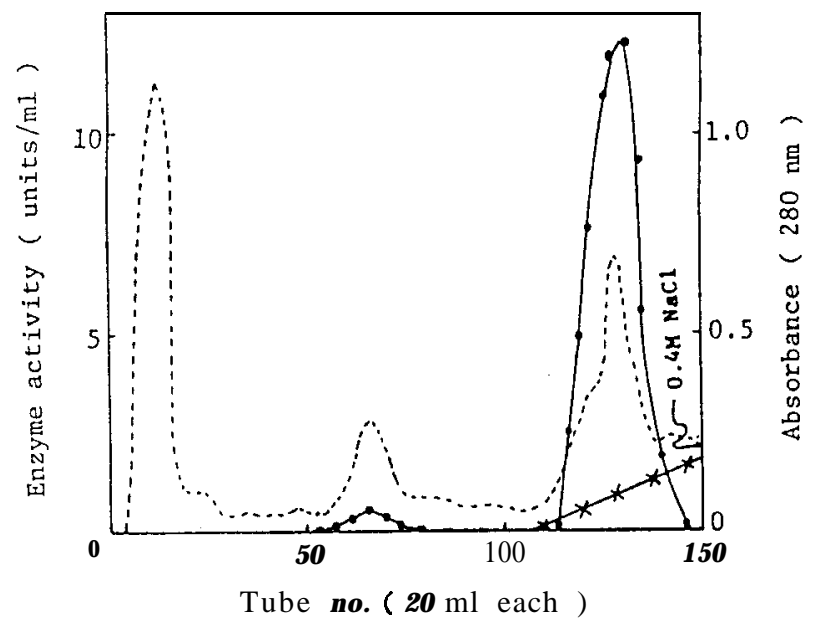

Fig. 1. Chromatography of endo- $\beta$-mannanase on a DEAE-Sephadex A-50 column. - - - enzyme activity; -- -, absorbance at $280 \mathrm{~nm} ;-\mathbf{x}-$, concentration of $\mathrm{NaCl}$.

$\mathrm{ml}$ of $0.4 \mathrm{M} \mathrm{NaCl}$ in the same buffer. The endo- $\beta$-mannanase emerged in tubes 116 to 140 as main enzyme fraction (Fig. 1). The endo- $\beta$-mannanase was further purified in the following steps.

Step 4. Chromatography on DEAE-Sephadex A-25

The endo- $\beta$-mannanase solution obtained above was dialyzed against $20 \mathrm{mM}$ sodium acetate buffer, $\mathrm{pH} 6.0$, containing $2 \mathrm{mM}$ calcium acetate. The dialyzed enzyme was applied to a column $(2 \times 32 \mathrm{~cm})$ of DEAE-Sephadex A-25 equilibrated with the same buffer. The column was eluted with a linear gradient between $400 \mathrm{ml}$ each of $20 \mathrm{mM}$ sodium acetate buffer, $\mathrm{pH} 6.0$, containing $2 \mathrm{mM}$ calcium acetate and $0.6 \mathrm{M} \mathrm{NaCl}$ in the same buffer. Active fractions were pooled and concentrated to $20 \mathrm{ml}$.

Step 5. Chromatography on Amberlite CG-50

All the buffers used in this step contained $1 \mathrm{mM}$ mercaptoethanol. The pooled enzyme solution was dialyzed against $20 \mathrm{mM}$ sodium acetate buffer, $\mathrm{pH}$ 5.2 , and then applied to a column $(1.5 \times 20 \mathrm{~cm})$ of Amberlite CG-50 equilibrated with the same buffer. The column was eluted a linear gradient between 250 $\mathrm{ml}$ of $10 \mathrm{mM}$ sodium acetate buffer, $\mathrm{pH} 5.2$, and $250 \mathrm{ml}$ of 1 . OM acetate buffer, $\mathrm{pH}$ 6.2. Active fractions were combined and, after the addition of calcium acetate to a final concentration of $2 \mathrm{mM}$, concentrated to $6 \mathrm{ml}$.

Step 6. Gel filtration on Sephadex G-100 column

The above enzyme solution was applied to a column $(2.2 \sim 100 \mathrm{~cm})$ of Sephadex G-100 equilibrated with $20 \mathrm{mM}$ sodium acetate buffer, $\mathrm{pH}$ 6.0, containing $2 \mathrm{mM}$ calcium acetate and $0.1 \mathrm{M} \mathrm{NaCl}$. The column was eluted with the same buffer. Active fractions were pooled and concentrated to $6 \mathrm{ml}$. 


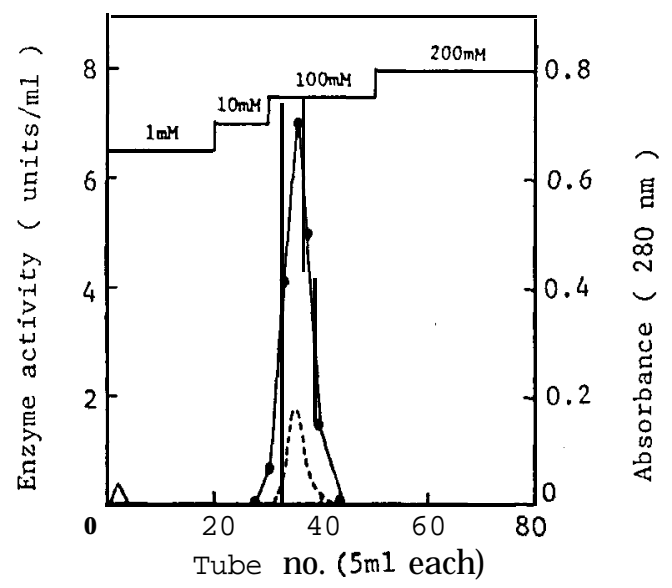

Fig. 2. Chromatography of endo- $\beta$-mannanase on a hydroxylapatite column. - - -, enzyme activity; -----, absorbance at $280 \mathrm{~nm} ;-$ - concentration of phosphate buffer.

The enzyme solution from the previous step was dialyzed against $1 \mathrm{mM}$ phosphate buffer, pH 6.8. The dialyzed enzyme was applied to a column $(1.2 \mathrm{x}$ $10 \mathrm{~cm}$ ) of hydroxylapatite equilibrated with the same buffer. Elution was performed by a stepwise increase in the concentration of phosphate buffer (Fig. 2). Fractions showed the enzyme activity were pooled and dialyzed against $50 \mathrm{mM}$ sodium acetate buffer, $\mathrm{pH}$ 6.0. The dialyzed solution was used as the purified endo- $\beta$-mannanase.

Analytical methods

Polyacrylamide disc gel electrophoresis was routinely performed with $7 \%$ gel in Tris-glycine buffer, pH 8.3, (Davis, 1964). Protein band was stained with Coomassie Brilliant Blue R-250.

Isoelectric focusing was carried out in a $110 \mathrm{ml}$ column (Vesterberg and Svensson, 1966). Ampholine concentration was $1 \%$ with a $\mathrm{pH}$ range from 5.0 to 7.0 in a sucrose gradient and the voltage was 600 volts. The run was performed at $2^{\circ} \mathrm{C}$ for $4 \% \mathrm{hr}$ and fractions of $2 \mathrm{ml}$ were collected.

Thin-layer chromatography of mannooligosaccharides was performed on Wako gel plate and developed with $n$-butano : isopropanol : water (50:25:20, $\mathrm{v} / \mathrm{v})$. The saccharides were visualized by spraying the plate with an anisaldehyde reagent.

\section{RESULTS AND DISCUSSION}

\section{Purification and homogeneity of endo- $\beta$-mannanase}

The purification and yield of the endo- $\beta$-mannanase are summarized in Table 1 . The purified enzyme preparation gave a single protein band on polyacrylamide disc gel electrophoresis (Fig. 3). 


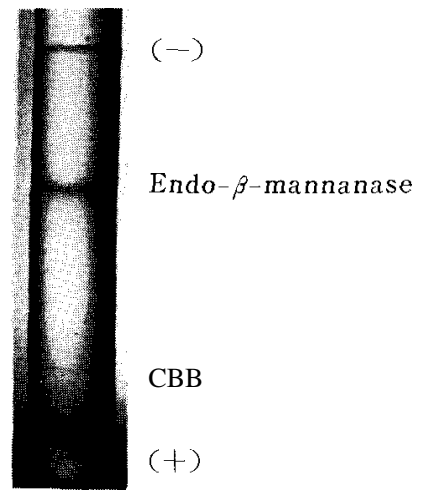

Fig. 3. Polyacrylamide gel electrophoresis of the final preparation of endo- $\beta$-mannanase. The purified enzyme was subjected to disc electrophoresis in $7.0 \%$ polyacrylamide gel at $\mathrm{pH}$ 8.3. Approximately $50 \mu \mathrm{g}$ of the enzyme was applied per tube. A current of $3 \mathrm{~mA}$ was supplied per tube and electrophored at room temperature. CBB, Coomassie brilliant blue R-250; $(+)$, anode; (-), cathode.

Table 1. Purification of endo- $\beta$-mannanase from the culture fluid of Aeromonas sp. F-25.

\begin{tabular}{lccccr}
\hline Procedure & $\begin{array}{c}\text { Total } \\
\text { protein } \\
(\mathrm{mg})\end{array}$ & $\begin{array}{c}\text { Total } \\
\text { activity } \\
\left.\text { (units } \times 10^{-3}\right)\end{array}$ & $\begin{array}{c}\text { Specific } \\
\text { activity } \\
\text { (units } / \mathrm{mg})\end{array}$ & $\begin{array}{c}\text { Yield } \\
\text { (\$) })\end{array}$ & $\begin{array}{c}\text { Purifica- } \\
\text { tion } \\
\text { (fold) }\end{array}$ \\
\hline Culture fluid & 38,300 & 17.1 & 0.446 & 100 & 1 \\
$\left(\mathrm{NH}_{4}\right)_{2}$ SO precipitation & 374 & 12.2 & 32.6 & 71.3 & 73. \\
DEAE-Sephadex A-50 & 134 & 9.3 & 69.4 & 54.4 & 156 \\
DEAE-Sephadex A-25 & 60.4 & 7.79 & 129 & 45.6 & 289 \\
Amberlite CG 50 & 17.5 & 3.22 & 184 & 18.8 & 413 \\
Sephadex G 100 & 4.8 & 0.965 & 201 & 5.61 & 451 \\
Hydroxylapatite & 2.7 & 0.532 & 197 & 3.11 & 442
\end{tabular}

\section{Characterization of endo- $\beta$-mannanase}

\section{Isoelectric point}

The isoelectric point of the enzyme was $\mathrm{pH} 5.6$ on isoelectric fozusing (Fig. 4).

\section{Molecular weight}

The molecular weight of the enzyme was estimated on a column of Sephadex G-100 which had been calibrated with the standard proteins. From logarithmic plots of the molecular weights versus the elution volumes of the proteins, it was estimated to be 24,000 (Fig. 5).

\section{Effects of $p H$}

The optimal $\mathrm{pH}$ of the enzyme was determined by using $50 \mathrm{mM}$ sodium acetate (pH 3.2-6.0), phosphate ( $\mathrm{pH} 5.0-7.0)$, and Tris-HCl (pH 7.0-8.0) buffers in the assay system. The maximal activity was observed at approximately pH 5.5 (Fig. 6). The stability of the enzyme at various pHs was studied by 


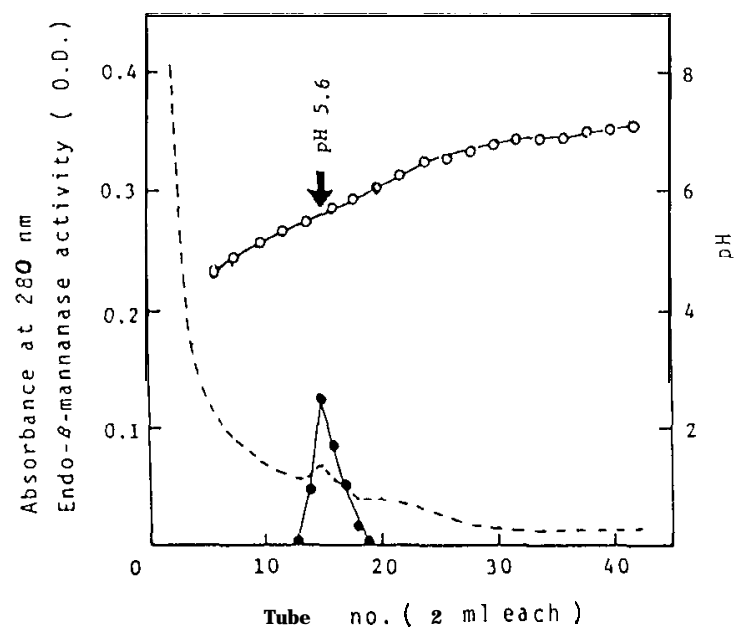

Fig. 4. Isoelectric focusing of endo-p-mannanase. - - - enzyme activity; $\cdots-\cdots-$, absorbance at $280 \mathrm{~nm} ;-\mathrm{O}-, \mathrm{pH}$.

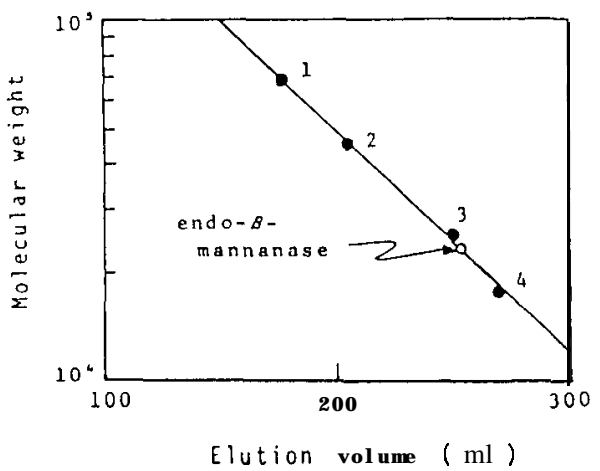

Fig. 5. Molecular weight determination of endo-p-mannanase by Sephadex G-100 column chromatography. 1, Bovine serum albumin $(67,000)$; 2, Ovalbumin $(45,000) ; 3$, Chymotrypsinogen-A $(25,003) ; 4$, Myoglobin $(17,800)$.

incubating it in $50 \mathrm{mM}$ sodium acetate $(\mathrm{pH} 3.26 .0)$, Tris- $\mathrm{HCl}(\mathrm{pH} 7.0-9.0)$, and glycine- $\mathrm{NaOH}(\mathrm{pH} 9.0-11)$ buffers at $20^{\circ} \mathrm{C}$ for $20 \mathrm{hr}$. Then, the remaining enzyme activity was assayed under the standard condition. The enzyme was stable between pH 5.0 to 9.0 (Fig. 7).

Effect of temperature

The enzyme was kept in $50 \mathrm{mM}$ sodium acetate buffer, $\mathrm{pH} 6.0$, for $15 \mathrm{~min}$ at various temperatures. The enzyme retained full activity at temperatures up to $45^{\circ} \mathrm{C}$, but lost its activity completely above $55^{\circ} \mathrm{C}$.

\section{Inhibitors}




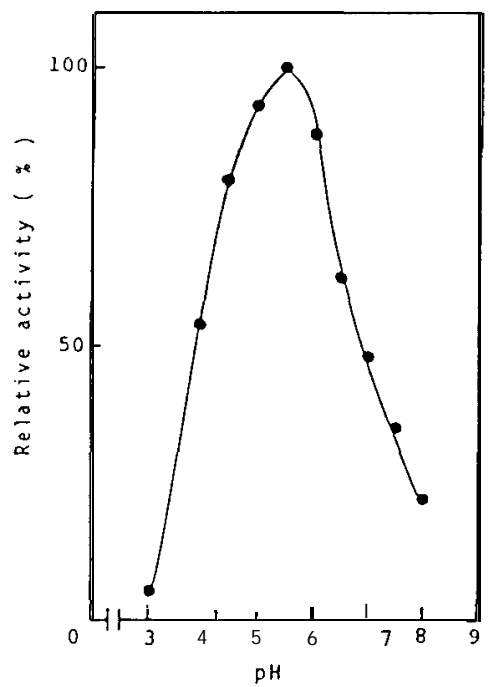

Fig. 6. pH-activity curve of endo- $\beta$-mannanase. $\mathrm{pH} 3.2-6$. 0 , acetate buffer; $\mathrm{pH}$ 5. U-7. G, phosphate buffer; $\mathrm{pH}$ 7.0-8. 0, Tris-HCl buffer.

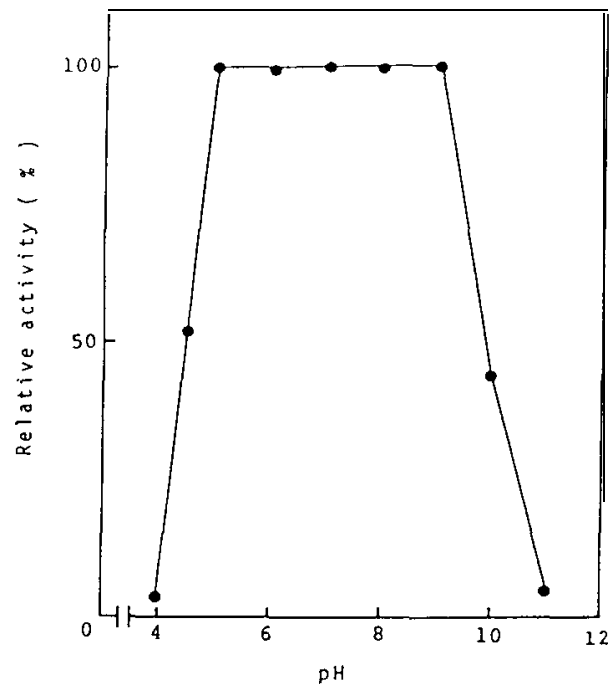

Fig. 7. pH-stability curve of endo-p-mannanase. pH 3.2-6.0, acetate buffer; $\mathrm{pH}$ 7.0-9.0, Tris-HCl buffer; pH9.0-11.0, glycine-NaOH buffer.

The effects of metal ions and other materials on the enzyme were investigated. The activity of the enzyme was almost completely inhibited by $1 \mathrm{mM}$ concentration of $\mathrm{Ag}^{\dagger}, \mathrm{Hg}^{2+}$, and $\mathrm{Cu}^{2+}$, while $\mathrm{Pb}^{2+}, \mathrm{Zn}^{2+}, \mathrm{Fe}^{3+}$, and $\mathrm{PCMB}$ produced 13, 14, 77, and $25 \%$ inhibition, respectively. $\mathrm{Na}^{+}, \mathrm{Mn}^{2+}, \mathrm{Mg}^{2+}$ and EDTA did not have any significant effects on the activity of the enzyme. $\mathrm{Ca}^{2+}$ stim- 
ulated the action at the same concentration.

\section{Action pattern of endo- $\beta$-mannanase}

Action of the enzyme on natural substrates

The enzyme attacked codium and coffee mannans to give mannobiose, mannotriose, and larger oligosaccharides. The enzyme could also hydrolyze konjac glucomannan and guar gum galactomannan (Fig. 8).

Action of the enzyme on several mannooligosaccharides

The enzyme could act on mannotetraose and larger mannooligosaccharides but not on mannobiose and -triose. The hydrolysis products from manno-

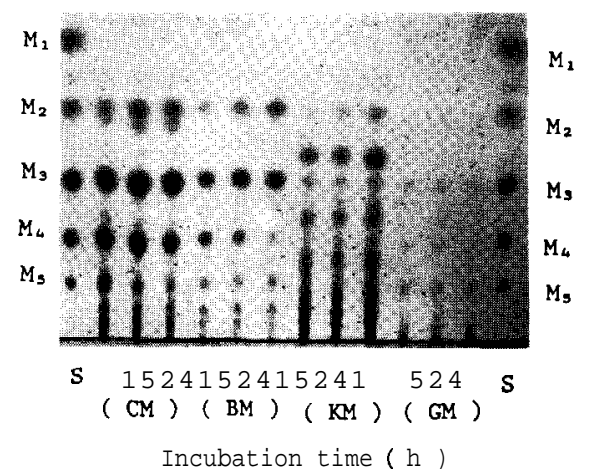

Fig. 8. Thin layer chromatogram of hydrolyzates of several $\beta$-mannanas with endo- $\beta$-mannanase: To $2 \mathrm{ml}$ of $0.5 \% \mathrm{CM}, \mathrm{BM}, \mathrm{KM}$ or $\mathrm{GM}$ dissolved in $10 \mathrm{mM}$ sodium acetate buffer, $\mathrm{pH} 5.5$, was added $1 \mathrm{ml}$ of the enzyme solution ( 1.0 unit), and the mixture was incubated at $37^{\circ} \mathrm{C}$. $\mathrm{M}_{1}$ $\mathrm{M}_{5}$, mannose-mannopentaose ; $\mathrm{S}$, standard; CM, codium mannan; BM, coffee mannan; KM, konjac glucomannan; GM, guar gum galactomannan.

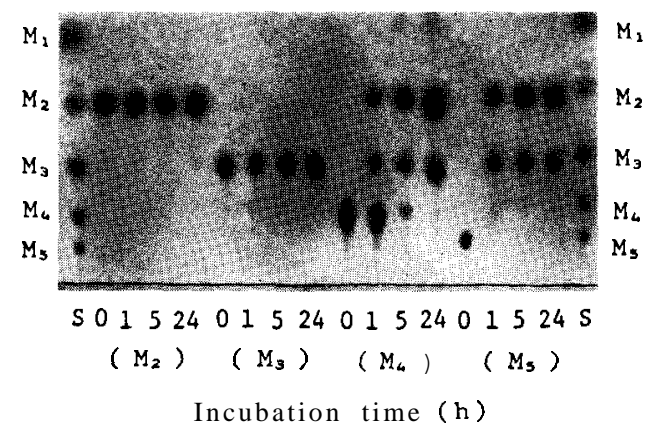

Fig. 9. Thin layer chromatogram of hydrolyzates of several mannooligosaccharides with endo-p-mannanase. The reaction mixture consisted of $0.5 \mathrm{ml}$ of $10 \mathrm{mM}$ sodium acetate buffer, $\mathrm{pH} 5.5$, containing 1.0 \% mannooligosaccharide and $0.5 \mathrm{ml}$ of the enzyme solution (1 unit), and it was incubated at $37 \%$. $\mathbf{M}_{\mathbf{1}}-\mathrm{M}_{5}$, mannose-mannopentaose ; S, standard. 
tetraose was mannose, mannobiose, and -triose. This shows that the enzyme attacks the $\beta$-1, 4-mannosidic linkage that was present apart two or three mannose residue from the non-reducing end in mannotetraose. Mannopentaose was hydrolyzed to mannobiose and -triose (Fig. 9).

Endo- $\beta$-mannanases have been detected from bacteria (Emi et al., 1972), fungi (Reese and Shibata, 1965), and from higher plants (Shimahara et al., 1975). These endo- $\beta$-mannanases have been classified into three types on the basis of their specificities; the first type is capable of attacking mannooligosaccharides larger than mannobiose, e.g. the $\beta$-mannanase from Aspergillus niger (Yamazaki et al., 1976), the second type attacking mannooligosaccharides larger than mannotriose, e.g. the $\beta$-mannanase from Bacillus subtilis (Emi et al., 1972), and the third type attacking mannooligosaccharides larger than mannotetraose, e.g. the $\beta$-mannanase from Rhizopus niveus (Hashimoto and Fukumoto, 1969). The endo- $\beta$-mannanase from Aeromonas sp. F-25 acted on oligomers larger than mannotriose, and not on mannobiose and -triose. Thus, the enzyme was ascertained to be similar to the endo- $\beta$-mannanase from B. subtilis, and classified as $1,4-\beta$-D-mannan mannanohydrolase (EC 3. 2. 1. 78. ).

Aeromonas sp. F-25 was found to produce a large quantity of endo- $\beta$-mannanase. The mannanase will be a powerful tool for determining structure? of $\beta$-mannans, and for preparing mannooligosaccharides of various sizes.

\section{ACKNOWLEDGEMENTS}

The author is particularly indebted to Associate Professor M. Kitamikado, Kyushu University, for his help in the preparation of this paper and the many useful suggestions for its improvement. His gratitude is expressed to Professor M. Toyomizu, Kyushu University, for reading the manuscript.

\section{REFERENCES}

Araki, T. and M. Kitamikado 1978 Distribution of mannan-degrading bacteria in aquatic environments. Bull. Japan.Soc. Sci. Fish., 44: 1135-1139

Araki, T. and M. Kitamikado $1981 \beta$-Mannanase of bacteria isolated from natural habitats. Bull. Japan. Soc. Sci. Fish., 41: 753-760

Araki, T. and M. Kitamikado 1982 Purification and characterization of a novel exo-p-mannanase from Aeromas sp. F-25. J. Biochem., 91: 1181-1186

Aspinall, G. O., E. L. Hirst, E. G. V. Percival and I. R. Williamson 1953 The mannans of ivory nut (Phytelephas macrocarpa) Part I. The methylation of mannan A and mannan B. J. Chem. Soc. [1953]: 3184-3188

Davis, B. J. 1964 Disk electrophoresis II. Method and application to human serum proteins. Ann. N. Y. Acad. Sci., 121: 404-413

Emi,S., J. Fukumoto and T. Yamamoto 1972 Crystallization and some properties of mannanase. Agr. Biol. Chem., 36: 991-1001

Hashimoto, Y. and J. Fukumoto 1969 Studies on the enzyme treatment of coffee beans I. Purification of mannanase of Rhizopus niveus and its action on coffee mannan. Nippon Nogeikagaku Kaishi, 43:317-322

Heyne, E. and R. L. Whistler 1948 Chemical composition and properties of guar polysac- 
charides. J. Am. Ckem. Soc., 70: 2249-2252

Jones, J. K. 1950 The structure of the mannan present in Porphyra umbilicalis. J. Ckem. Soc.,[1950] : 3292-3295

Love, J. and E. Percival 1964 The polysaccharides of the green seaweed Codium fragile. J. Chem.Soc.,[1964]: 3345-3350

Reese, E. T. and Y. Shibata $1965 \beta$-Mannanase of fungi. Can. J. Microbiol,, 11: 167-183

Shimahara, H., H. Suzuki, N. Sugiyama and K. Nisizawa 1975 Partial purification of $\beta$-mannanase from the konjac tubers and their substrate specificity in relation to the structure of konjac glucomannan. Agr. Biol.Chem., 39: 301-312

Somogyi, M. 1952 Notes on sugar determination. J. Biol.Chem., 195: 19-23

Sugiyama, N., H. Shimahara and T. Andoh 1972 Studies on mannan and related compounds I. The purification of konjac mannan.Bull. Ckem. Soc. Japan, 45: 561-563

Vesterberg, 0. and H. Svensson 1966 Isoelectric fraction, analysis, and characterization of ampholytes in natural pH gradients. Acfa Ckem. Scand., 20: 820-834

Wolfrom, M. L., M. L. Laver and D. L. Patin 1961 Carbohydrate of the coffee beans II. Isolation and characterization of a mannan. J. Org. Chem., 26: 4533-4535

Yamazaki. N., M. Sinner and H. H. Dietrichs 1976 Isolation and properties of $\beta-1,4-$ mannanase from Aspergillus niger.Holzforshung., 30: 101-109 